\title{
In Vitro Investigation of the Cytotoxic Effects of Different Detergent-Containing Children's Toothpastes on Human Gingival Epithelial Cells
}

Sinem Birant ( $\sim$ sinembirant@iuc.edu.tr )

Istanbul University-Cerrahpasa

Yazgul Duran

Marmara University

Tunc Akkoc

Marmara University

Figen Seymen

Istanbul University

Research Article

Keywords: toothpaste, stem cell, Anneksin V, detergent, SLS

Posted Date: October 6th, 2021

DOl: https://doi.org/10.21203/rs.3.rs-885708/v1

License: (9) This work is licensed under a Creative Commons Attribution 4.0 International License. Read Full License 


\section{Abstract}

Background: This study aimed to evaluate possible cytotoxic effects to gingival epithelial cells exposed to children toothpastes containing different detergent.

Methods: Tissues required fort he isolation of human gingival epithelial cells were obtained by biopsy during the extraction of the impacted third molar tooth. Toothpaste solutions of different concentrations were prepared from five different children's toothpastes with different detergent contents. Isolated gingival epithelial cells were stimulated with experimental groups consisting of toothpaste solutions (Colgate, Sensodyne, Splat, Nenedent, Perlodent) at different concentrations and a control group consissting of complete Dulbocco's modified eagle medium. After the experiments, cell viability was evaluated using flow cytometry. Data analysis were done using One Way ANOVA test and Tukey post-hoc test.

Results: In all experimental groups, there was a decrease in live cell rates and an increase in dead cell rates due to increased concentration. The statistically highest live cell ratios were detected in Splat's toothpaste solutions after the control group and the group with the lowest viability values was determined in Colgate group $(p<0.05)$.

Conclusions: According to the results of the study, it was observed that toothpastes containing SLS affected the viability of cells more negatively than toothpastes with other detergent contents.

\section{Introduction}

Dental plaque is defined as a dynamic biofilm ecosystem consisting of more than 100 bacterial species, desquamated epithelial cells, salivary glycoproteins, leukocytes, macrophages and food residues that accumulate on tooth surfaces $[1,2]$.

Tooth decay and periodontal diseases are among the most common bacterial infections. It is reported that the most important factor of these diseases is dental plaque deposited on the tooth surface [3]. For this reason, it is critical to remove dental plaque from the tooth surface and provide oral hygiene in the prevention of tooth decay and gum diseases. The simplest method to apply in this regard is to give individuals the habit of brushing their teeth. The most commonly used toothpastes during tooth brushing are among the most effective cosmetic and therapeutic agents in routine use, and among all dental products, they are among the most widely used by consumers $[4,5,6,7]$.

There are many components in toothpaste, whose activities and functions are different from each other. Among these components, abrasives, water and moisturizers are present in toothpastes by $20-40 \%$, detergents $1-2 \%$, binding agents and sweeteners $2 \%$, therapeutic agents $5 \%$, colorants and preservatives $1 \%$. The presence of these components or their concentration in toothpaste can cause undesirable side effects $[8,9]$. 
Detergents are substances that reduce surface tension known as surfactants. They have two groups, hydrophilic and hydrophobic $[10,11]$. While the long hydrocarbon chain forms the water-repellent (hydrophobic) part of the molecule, it also provides the molecule with surface active properties. The polar group forms the water-loving (hydrophilic) part of the molecule and enables it to dissolve in water. The combination of these polar and apolar groups is defined as the amphiphilic structure. Thanks to the amphiphilic structure, surfactants can be dissolved in both polar and apolar solvents. While detergents adhere to water molecules with their polar parts due to these chemical properties, they ensure the removal of dirt from the environment by holding on to the dirt with their apolar parts $[10,11,12,13]$.

Detergents are classified as anionic, cationic, amphoteric and nonionic detergents according to the ionic charge of the hydrophilic group they contain. Anionic and amphoteric detergents are frequently used in toothpaste. Sodium lauryl sulfate, sodium methy cocoyl taurate (adinol), sodium streate (sodium octadecanoate), sodium lauryl sarcosinate, sodium C12-14 olefin sulfonate, sodium C14-16 olefin sulfonate from anionic detergents and cocaamidopropyl betaine among amphoteric detergents are surfactants used frequently in toothpastes. In addition to their foaming and cleansing properties, they are routinely added to toothpastes due to their antibacterial and plaque inhibition properties $[14,15,16,17]$.

Sodium lauryl sulfate is a detergent that is often used in toothpastes with a ratio of $0.5 \%$ to $2 \%$. SLS prevents the growth of some microorganisms by adsorption to the cell wall, penetration through the cell wall, interaction with the cell membrane, lipids and proteins, leakage of intracellular components with an increase in cell permeability and lysis in the cell $[18,19]$. It has been reported in studies that SLS increases plaque inhibition, decreases S. Mutans penetration, decreases lactate production, glucosyltransferase activity and the amount of extracellular polysaccharide created by S. mutans $[20,21,22]$. Despite these positive features, some toxic effects of SLS have also been reported. Oral epithelial destruction, ulcerations and inflammations caused by SLS have been observed in clinical studies. It has been reported that SLS in the toothpaste denatures the glycoproteins of the mucin layer, causing the barrier function of the oral mucosa to deteriorate, and the gingiva and buccal mucosa to be more sensitive to irritants such as exogenous antigens. It has also been stated that SLS may be responsible for a decrease in the keratinization level of the human oral epithelium. Sodium lauryl sulfate has also been reported to cause irritation of the oral mucosa in patients with dry mouth and the use of SLS is also associated with recurrent aphthous ulcers $[23,24,25,26]$. Although SLS is the most commonly used surfactant among toothpastes, surfactants with less side effects such as betaines are also used in toothpastes.

Cocoamidopropyl betaine, an amphoteric detergent, has been reported to have less mucosal irritation and foaming effect than SLS, and it is more biocompatible $[27,28]$. The aim of this study was to investigate the effects of different detergent-containing children's toothpastes on the viability of human primary gum epithelial cells.

\section{Materials- Methods}

The study was approved by the ethics committee of Istanbul University, Faculty of Dentistry (170/2017) according to Helsinki Declaration guidelines. 


\section{Isolation and charactarization of gingival epithelial cells (GECs)}

5 fully impacted human third molars, which were removed from systemically healthy patients (aged 1825 years) were used for tissue biopsy. Gingival tisues surrounding the tooth sockets were collected immediately after tooth extraction. For the isolation of gingival epithelial cells, the gum tissue was incubated at $4^{\circ} \mathrm{C}$ in $0.4 \%$ dispase overnight. The epithelium strips were then mechanically separated and trypsinized in $0.05 \%$ trypsin $/ 0.53 \mathrm{mM}$ EDTA (Gibco, Grand Island, NY, USA) at $37^{\circ} \mathrm{C}$ for $10-15 \mathrm{~min}$. After strong pipetting, the cell suspension was centrifuged at $700 \mathrm{~g}$ for $5 \mathrm{~min}$ and the cell pellet was resusspended in keratinocyte growth medium (Dermalife Basal Medium; Lifeline, Walkersville, MD, USA). The cells were transferered to $\mathrm{T}-25 \mathrm{~cm}^{2}$ flask and were placed in the incubator which provided $5 \%$ $\mathrm{CO}_{2}$ environment at $37^{\circ} \mathrm{C}$. The keratinocyte growth medium was changed every 2 days and the proliferation and spreading of the cells on the flask was monitored at regular intervals by invert miscroscope (EVOS-AMG, Thermo Fisher Scientific, Waltham, MA, USA).

Cells were fixed on the slide using $95 \%, 70 \%$ and $50 \%$ alcohol, respectively, at room temperature. Then, the fixation process was completed by dipping the slide into distilled water. Staining was performed with hematoxylin (Sigma-Aldrich, St. Louis, MO, USA) for 8 min. After staining, it was washed with distilled water and the second staining process was started with Eosin (Sigma-Aldrich). After staining with eosin for 90 seconds, the cells were dehydrated with $95 \%$ alcohol and then dipped in xylol 20 times. Microscope slides were fixed using Permount (Fischer Scientific, Pittsburgh, PA, USA) and epithelial cells were analyzed by Binocular Research Microscope (Olympus BH2-RFCA) for characterization.

\section{Preparation of toothpaste solutions}

The toothpastes used in this study were Colgate6+, Sensodyne Pronamel 6+, Nenedent (4-9), Perlodent Junior $6+$, Splat Juicy. The different detergent contents and other properties of these toothpastes can be seen in Table 1. Toothpaste solutions of $80 \%, 50 \%, 20 \%$ and $0.4 \%$ concentrations of these toothpastes used in the study were prepared by the method in our previous study and homogenized extraction liquids were obtained from toothpastes for cell viability experiments [29] (Birant et al. 2021).

\section{Evaluation of cell viability by flow cytometry}

Gingival epithelial cells ( $5 \times 10^{5}$ cells) were plated into 48-well plates separately to perform viability experiments in each concentration of toothpaste solution. The viability experiments were carried out following the method used in our previous study (Birant et al. 2021). Gingival epithelial cells were exposed to toothpaste solutions for 2 minutes, , washed with DPBS (Dulbecco's phosphate buffered saline) (Gibco, Grand Island, NY, USA) and suspended in serum-free medium. $4 \mu$ l of Annexin V (BD Biosciences, CA, USA) was added to the tubes and the tubes were kept in a dark environment for 10 
minutes. $200 \mu \mathrm{l}$ of binding buffer was added and centrifuged at $1500 \mathrm{rpm}$ for $5 \mathrm{~min}$. Tubes were vortexed by adding $200 \mu \mathrm{l}$ binding buffer. Then, $10 \mu \mathrm{l}$ propidium iodide was added to the tubes to read the rates of viable, necrosis, early and late apoptotic cells in cells exposed to toothpaste solutions. The experiments with flow cytometry were repeated 5 times, and the average of the results obtained was calculated to determine the rates of viable, early apototic, late apoptotic and necrotic cells [29]. (Birant et al. 2021).

\section{Statistical Analysis}

The obtained datas were analyzed using the IBM SPSS V23 statistical program. While One Way ANOVA Test eas used for multiple comparisons, Tukey Post-Hoc Test was used for pairwise comparisons.

\section{Results}

\section{Isolation and Characterization of Cells}

It was observed that the isolated gingival epithelial cells had a cylindrical and cubic morphology by following their proliferation and reached a confluent structure from the 0th to the 3rd passage (Figure 1). The microscope image obtained as a result of staining with hematoxylin and eosin for the characterization of isolated gingival epithelial cells showed that the cells exhibited a cubic morphology (Figure 2).

\section{Cell viability in cells cultured exposured to the children's toothpaste containing the different detergent content}

After exposure to the different toothpaste solutions at different toothpaste concentrations, viable and dead cell ratios were determined graphically according to Annexin-V / PI positive and negativity. Annexin V (-) and PI (-) live, Annexin V (+) and PI (-) early apoptotic cell, Annexin V (+) and PI (+) late apoptotic cell, Annexin $\mathrm{V}(-)$ and $\mathrm{PI}(+)$ considered as a necrotic cell. The flow cytometry graphs of the control group (CDMEM) in Figure 3, the Splat group in Figure 4, and the Sensodyne group in Figure 5, the Nenedent group in Figure 6, the Perlodent group in Figure 7 and the Colgate group in Figure 8 show the average viable, early apototic, late apoptotic and necrotic cell ratios.

The percentages of the cell viability on GECs were represented in Table 2. The lower percentage of viable cells was observed in Colgate group containing SLS $(p<0.05)$. The cell viability rates in the Control group were found statistically higher than all groups at $20 \%, 50 \%$ and $80 \%(p<0.05)$. After the Control group, the highest viability ratios was observed in the detergent-free Splat group followed by the Sensodyne experimental group containing CABP $(p<0.05)$. Nenedent group had percentage of cell viability than Perlodent group at $50 \%$ and $80 \%$ concentrations $(p<0.05)$ (Table 2$)$. 
The percentages of dead cell rates on GECs is represented in Table 3,4,5. In the evaluation of early apoptotic cell rates, a statistically significant difference was found in the comparisons between the groups at all concentrations except $0.4 \%(p<0.05)$. While the lowest early apoptosis rates were found in the Control and Splat groups at $20 \%, 50 \%$ and $80 \%$ concentrations, there was no statistically significant difference between these two groups ( $p>0.05$ ). The highest early apoptotic cells rates at $20 \%$ concentration was found in the Colgate and Nenedent groups. Early apoptosis rates in the Colgate group at $50 \%$ concentration were found to be statistically significantly higher than all groups $(p<0.05)$. At $80 \%$ concentration, the highest rates of early apoptosis were detected in the Nenedent group, followed by the Colgate and Perlodent groups, respectively $(p<0.05)$ (Table 3$)$.

In the evaluation of late apoptotoic cell rates, a significant difference was found between the groups at all concentrations $(p<0.05)$. While the highest late apoptotic cell rates at all concentrations were usually detected in the Colgate group, no significant difference was found between Colgate and Perlodent at $0.4 \%$ concentration, Colgate, Nenedent and Perlodent at 50\% concentrations ( $p>0.05$ ) (Table 4).

In the evaluation of the rate of necrotic cell rates, a statistically significant difference was found in the comparisons between the groups $(p<0.05)$. The lowest rates of necrotic cells at all concentrations were detected in the Splat and Sensodyne groups after the control group (Table 5).

\section{Discussion}

Detergents, one of the toothpaste components, are frequently used in removing plaque, due to their antimicrobial properties. However, it is stated that besides these positive properties, they also have the potential to adversely affect the oral mucosa [30].

Clinical intraoral side effects such as mucosal sensitivity, epithelial desquamation and recurrent aphthous ulcerations in in vitro studies point to the possible problems of these ingredients used in adult toothpaste $[27,31,32]$. Studies examining the effects of these components in children's toothpastes on intraoral tissues are very few. When looking at the contents of children's toothpaste, it is seen that many paste contents contain SLS as a type of detergent. However, considering the side effects of SLS, the different degree of keratinization and morphology of the gums of children suggests that these side effects may occur more in children.

Therefore, in this study, the effects of 5 different children's toothpaste with different detergent content on cells were investigated. There are different evaluation methods to investigate the effects on cells, to determine the toxic effects of the materials to be used or to investigate their biocompatibility. These tests can be classified as clinical use tests, in vivo animal experiments and in vitro cell culture tests. Among these alternative methods, cell culture tests are frequently used in cytotoxicity studies due to their ability to mimic the physiological conditions of living tissues. In addition, cell culture studies have many advantages such as rapid application, repeatability, standardization, low cost, easy control of the experimental environment during the experiment and not being affected by different individual factors $[33,34]$. Since there are some ethical and legal problems in other test methods, in vitro cell culture tests 
constitute the starting point of such studies in biocompatibility and cytotoxicity studies. In this study, in vitro cell culture tests were preferred to determine the effects of toothpastes on cells.

The cell type used in cell culture studies should be selected in relation to the area of use of the material whose cytotoxic effects are investigated. Primary cell cultures or continuous cell lines are used in studies as a biological system in biocompatibility tests. It is stated that continuous cell lines such as L929, 3T3, HSC-2, MRC- 5 can be used in the cytotoxicity assessment tests of materials used in dentistry, since they can be obtained more easily than primary cell cultures and have rapid reproduction potential. However, since primary cell cultures are more sensitive than continuous cell lines, they are biological systems that best reflect the original physiological state, despite the difficulties that arise during the production phase and the long time to produce $[33,35,36,37,38,39]$. For this reason, it was preferred to create a primary cell culture in this study, considering the creation of experimental conditions closer to in vivo conditions. Gingival epithelial cells were used as a biological system in this study, since the majority of oral tissues that toothpastes come into contact with during tooth brushing are gum tissues.

In studies for the characterization of gingival epithelial cells, the method of determining epithelial cells specific CK13 and Vimentin genes by PCR, analysis of phenotypic properties of cells by transmission electron microscopy, determination of a specific epithelial marker cytokeratin by immunofluorescence method, staining of cells with Papanicolau staining method and analysis under light microscopy. methods were used [40]. In this study, the cells, which are easier and quicker to apply than other methods and are also more cost-effective, were stained with hematoxylin and eosin dyes after fixation with alcohol on the slide, and the cells were analyzed under light microscopy, and the presence of epithelial cells was determined.

Many in vitro tests such as MTT, trypan blue exclusion test, micronucleus are used to determine cell viability. $[27,28,41,42,43,44,45,46]$. Flow cytometry analysis is frequently recommended in terms of providing more reliable, faster and more sensitive results than other methods in evaluating cell viability and cytotoxicity [47]. In addition to determining cell viability, information about different properties of cells such as immunophenotypic properties, enzyme activities, and specific markers of the cell can be obtained with this method [48]. In addition, the separation of apoptotic and necrotic cells with this method is important in terms of different biological responses of these two types of death [49]. In this study, since gingival cells are labeled with Annexin $\mathrm{V}$ and propidium iodide dyes, since they give faster, more sensitive and reliable results compared to alternative methods used in cell culture studies, it was ensured that live, early apoptotic, late apoptotic and necrotic cells were determined by flow cytometry analysis.

In the literature, changes caused by SLS, which is frequently used in toothpaste, on the oral mucosa have been reported. In addition, in a few studies examining the effects of SLS on cells, it has been stated that they have a negative effect on cell viability $[27,28,50,51,52,53,54,55]$. In this study, SLS, sodium lauryl sarcosinate, sodium C14-16 olefin sulfonate, CAPB containing toothpastes which are reported to be more biocompatible than SLS, toothpaste without detergent and CDMEM were selected as experimental 
groups. While determining the concentrations of toothpaste solutions in cell viability experiments, similar studies have been examined and optimized as $0.4 \%, 20 \%, 50 \%$ and $80 \%$. In addition, in this study, the stimulation time of toothpaste solutions with cells was determined as 2 minutes, since the brushing time was 2 minutes under normal conditions [27,28,41].

When the studies on detergents are examined; Herlofson et al. found a positive relationship between oral desquamation and SLS in their study [56]. Melsen et al examined the effect of SLS on monoflurophosphate, and it was stated that SLS reduced the amount of fluoride taken up by the enamel [57]. Rantanen et al reported that toothpastes containing SLS have an irritating effect on the mucosa [58]. Shim et al. Investigated the effect of SLS on recurrent aphthous stomatitis and showed that SLS significantly increased the incidence of ulcers, the duration of ulcers in the mouth, and the pain score [54].

In this study, when the viability rates of different detergent-containing children's toothpaste solutions onhuman gingival epithelial cells were evaluated, it was seen that the lowest proportion of viable cells was in toothpaste solutions containing SLS. After the control group, the highest vitality values were detected in toothpaste without detergent content, followed by toothpaste containing CAPB. The effects of this study on cell viability Cvikl et al.'s findings in studies examining the effects of adult toothpastes and children's toothpaste on cells $[27,28]$. Moore et al. also found that cell viability rates in SLS and betaine containing toothpastes were lower than the control group. These findings are also similar to the findings in our study.

In the literature, the effects of toothpastes on cells have been examined only in terms of living cell proportions. In this study, early apoptotic, late apoptotic and necrotic cell ratios were evaluated as well as the live cell ratios. In the comparisons between the groups, the Colgate group generally shows the highest value in terms of early apoptotic, late apoptotic and necrotic cell ratios, while Splat and the control group generally have similar values in terms of cell death type rates. Considering that SLS increases cellular permeability by causing denaturation of cellular proteins in this study, we think that the opening of the pores between cells may cause the release of apoptosis-inducing proteins into the cytosol and ultimately stimulate apoptosis / necrosis mechanisms. It has been reported that stimulation of apoptosis and necrosis mechanisms in gingival epithelial cells may prevent periodontal wound healing and prolong the healing period $[59,60,61,62]$. In this study, it is thought that the increase in the ratio of apoptotic and necrotic cells of SLS-containing toothpaste may delay the healing time of periodontal diseases and oral aphthous ulcers and adversely affect wound healing.

\section{Abbreviations}

GEC: gingival epithelial cells; SLS: sodium lauryl sulfate; CDMEM: complete dulbecco's modified eagles medium; CABP: cocoamidopropyl betaine; DPBS: dulbecco's phosphate buffered saline. 


\section{Declarations}

\section{Authors' Contributions}

Designing the study by Figen Seymen, Sinem Birant; generating the data by Sinem Birant; analyses the data by Yazgul Duran, Tunc Akkoc; writing the paper by Sinem Birant; approved the final version of this paper by Sinem Birant, Yazgul Duran, Tunc Akkoc, Figen Seymen.

\section{Funding}

This study was supported by the Research Fund of Istanbul University, project no: 26391.

\section{Data Availability of data and materials}

Data and materials are available and transparent.

\section{Declarations}

\section{Ethics approval:}

The study was approved by the ethics committee of Istanbul University, Faculty of Dentistry (170/2017) following Helsinki Declaration guidelines.

\section{Consent to participate:}

Written consents were collected from all the participants before enrollment.

\section{Consent for publication:}

All contributing authors agree to the publication of this article. Competing interests The authors declare no competing interests.

\section{Competing interest:}

The authors do not have any conflict of interest. 


\section{References}

1. Rosan B, Lamont RJ. Dental plaque formation. Microb and Infect. 2000;2:1599-607.

2. Takeshita T, Yasui M, Shibata Y, Furuta M, Saeki Y, Eshima N, et al. Dental plaque development on a hydroxyapatite disk in young adults observed by using a barcoded pyrosequencing approach. Sci Report. 2015;5:1-9.

3. Walsiluk A. Fluoride compounds in dental caries prophylaxis in children and adolescents- Review of polish literature. Przegl Epidemiol. 2017;71:603-11.

4. Claydon NC. Current concepts in toothbrushing and interdental cleaning. Periodontol 2000. 2008;48:10-22.

5. Trubey RJ, Moore SC, Chestnutt IG. Parents reasons for brushing or not brushing their child's teeth: a qualitative study. Int J Paediatr Dent. 2014;24(2):104-12.

6. Deery $C$, Heanue M, Deacon S, Robinson PG, Walmsley AD, Worthington $H$, et al. The effectiveness of manual versus powered toothbrushes for dental health: A systematic review. J Dent. 2004;32:197211.

7. Wilder RS, Bray KS. Improving periodontal outcomes: merging clinical and behavioral science. Periodontol 2000. 2016;71:65-81.

8. Welbury R., Duggal M., HoseyT. M. Paediatric dentistry. 3rd ed. Oxford University Press; 2005.

9. Ozkocak CBB, Karaarslan SE, Aytac F. Saliva proteins and their effects on caries. Turkey Dental Clinics J Sci. 2017;23:56-64.

10. Chambers HF. Miscellaneous antimicrobial agents; disinfectants, antiseptic, sterilants. In: Katzung BG, editor. Basic\&Clinical Pharmacology. 10th ed. Connecticut, Appleton\&Lange; 2007. pp. 803-11.

11. Ozyurt M. Aldehyde, peroxygen and peracetic acid and other disinfectants that do not contain chlorine donating agents and are recommended as instrument disinfectants, their general use and antimicrobial effectiveness. In: Gunaydın M, Sanic, A, Gurler B, editors. 4th National Sterilization Disinfection Congress, Congress Book. Scientific Medicine Publishing House, Ankara; 2005. pp. 180199.

12. Ananthapadmanabhan KP, Moore DJ, Subramanyan K, Misra M, Meyer F. Cleansing without compromise: the impact of cleansers on the skin barrier and the technology of mild cleansing. Dermatol Ther. 2004;17:16-25.

13. Walters KA, Bialik W, Brain KR. The effects of surfactants on penetration across the skin. Int J Cosmetics Sci. 1993;15:260-70.

14. Shah SK, Niraula TP, Bhattarai A, Chatterjee SK. A comparative study of cationic and anionic surfactants on the micellar behavior through different composition of methanol-water mixed solvent. Conductometric Method Bibechan. 2012;8:37-45.

15. Forward GC, James AH, Barnett P, Jackson RJ. Gum health product formulations: what is in them and why? Periodontol. 2000;15:32-9. 
16. Petersen FC, Assev S, Scheie AA. Combined effects of NaF and SLS on acid and polysaccharide formation of biofilm and planktonic cells. Arch Oral Biol. 2006;51:665-71.

17. Buma R, Maeda T, Kamei M, Kourai H. Pathogenic bacteria carried by companion animals and their susceptibility to antibacterial agents. Biocontrol Sci. 2006;11:1-9.

18. Law V, Seow WK. A longitudinal controlled study of factors associated with mutans streptococci infection and caries lesion initiation in children 21 to 72 months old. Pediatr Dent. 2006;28:58-65.

19. Nordstrom A, Mystikos C, Ramberg P, Birkhed D. Effect on denovo plaque formation of rinsing with toothpaste slurries and water solutions with a high fluoride concentration $(5,000 \mathrm{ppm})$. Eur $\mathrm{J}$ Oral Sci. 2009;117:563-7.

20. Moran J, Addy M, Newcombe R. The antibacterial effect of toothpastes on the salivary flora. J Clin Periodontol. 1988;15:193-9.

21. Moran J, Addy M, Newcombe R. Comparison of the effect of toothpastes containing enzymes or antimicrobial compounds with a conventional fluoride toothpaste on the development of plaque and gingivitis. J Clin Periodontol. 1989;16:295-9.

22. Evans A, Leishman SJ, Walsh LJ. Inhibitory effects of children's toothpastes on Streptococcus mutans, Streptococcus sanguinis and Lactobacillus acidophilus. Eur Arch Paediatr Dent. 2015;16:219-26.

23. Macdonald JM, Tobin CA, Burkemper NM, Hurley MY. Oral Leukoedema with mucosal desquamation caused by toothpaste containing sodium lauryl sulfate. Case Let. 2015;97:4-5.

24. Neppelberg E, Costea DE, Vintermyr OK, Johannessen AC. Dual effects of sodium lauryl sulphate on human oral epithelial structure. Experiment Dermatol. 2007;16:574-9.

25. Siegel IA, Gordon HP. Surfactant-induced alterations of permeability of rabbit oral mucosa in vitro. Exp Mol Pathol. 1986;44:132-7.

26. Ahlfors EE, Lyberg T. Contact sensitivity reactions in the oral mucosa. Acta Odontol Scand. 2001;59:248-54.

27. Cvikl B, Lussi A, Moritz A, Gruber R. The in vitro impact of toothpaste extracts on cell viability. Eur Oral Sci. 2015;123:179-85.

28. Cvikl B, Lussi A, Moritz A, Gruber R. Dentifrices for children differentially affect cell viability in vitro. Clin Oral Invest. 2017;21:453-61.

29. Birant S, Duran Y, Gokalp M, Akkoc T, Seymen F. Effects of different-containing children's toothpastes on the viability, osteogenic and chondrogenic differentiation of human dental periodontal ligament stem cells and gingival stem cells in vitro. Tissue and Cell 2021,72:1-12.

30. Lawrence LM., Farquharson A, Brown RS, Vatanka HO. Oral tissue irritants in toothpaste: a case report. J Clin Pediatr Dent. 2013;38:75-8.

31. Herlofson BB, Barkvoll P. Oral mucosal desquamation caused by two toothpaste detergents in an experimental model. Eur J Oral Sci. 1996;104:21-6. 
32. Skaare AB, Rolla G, Barkvoll P. The influence of triclosan, zinc or propylene glycol on oral mucosa exposed to sodium lauryl sulphate. Eur J Oral Sci. 1997;105:527-33.

33. Craig RG, Powers JM, Sakaguchı RL. Craig's Restorative Dental Materials.12th ed. St. Louis: Mosby; 2006.

34. Schmalz G. Use of cell cultures for toxicity testing of dental materials- advantages and limitations. J Dent. 1994;22:6-11.

35. Arenholt-Bindslev D, Bleeg H. Characterization of two types of human oral fibroblast with a potential application to cellular toxicity studies; tooth pulp fibroblasts and buccal mucosa fibroblasts. Int Endod J. 1990;23:84-91.

36. Illeperuma RP, Park YJ, Kim JM, Bae JY, Che ZM, Son HK, et al.. Immortalized gingival fibroblasts as a cytotoxicity test model for dental materials. J Mater Sci Mater Med. 2012;23:753-62.

37. International Organization for Standardization. Dentistry- Biological evaluation of medical devices. Tests for in vitro cytotoxicity. ISO 10993-5. 2009. https://www.iso.org/standard/36406.html. Accessed 13 Feb.2019

38. Schmalz G. Concepts in biocompatibility testing of dental restorative materials. Clin Oral Invest.1997;1:154-62.

39. Tuncer S, Demirci M. Biocompatibility Evaluations of Dental Materials. J Atatürk Univ Dentist.2011;21:141-9.

40. Russo FB, Pignatari GC, Fernandes IR, Dias JLRM, Beltrao-Braga PCB. Epithelial cells from oral mucosa: How to cultivate them? Cytotechnol. 2016;68:2105-14.

41. Ghapanchi J, Kamali F, Moattari A, Poorshahidi S, Shahin E, Rezazadeh F, et al. In vitro Comparison of cytotoxic and antibacterial effects of 16 commercial toothpastes. J Int Oral Health. 2015;7:39-43.

42. Fiori J, Teti G, Gotti R, Mazzotti G, Falconi M. Cytotoxic activity of guaiazulene on gingival fibroblasts and influence of light exposure on guaiazzulene-induced cell death. Toxico In Vitro. 2011;25:64-72.

43. Eyuboglu GB, Yesilyurt C, Erturk M. Evaluation of cytotoxicity of dentin desensitizing products. Oper Dentist. 2015;40:503-14.

44. Kalil Bussadori S, Marcilio Santos E, Cardoso Guedes C, Jansiski Motta L, Santos Fernandes KP, Mesquita-Ferrari RA, et al. Cytotoxicity assessment of casein phosphopeptide-amorphous calcium phosphate (CPP-ACP) paste. ConScient Saude. 2010;9:354-9.

45. Fernandes JPS, Mello Moura ACV, Marques MM, Nicoletti MA. Cytotoxicity evaluation of Curcuma zedoaria Roscoe fluid extract used in oral hygiene products. Acta Odontol Scand. 2012;70:610-4.

46. Olgun Erdemir E, Sengun A, Ulker M. Cytotoxicity of mouthrinses on epithelial cells by micronucleus test. Eur J Dent. 2007;1:80-5.

47. Zhou H, Shen Y, Wang Z, Li L, Zheng Y, Hakkinen L, et al. ve ark. In Vitro Cytotoxicity Evaluation of a Novel Root Repair Material. J Endod. 2013;39:478-83.

48. Kanev MO, Gokalp Muranlı FD. Flow cytometry and usage areas. J SAÜ Fen Bil. 2016;20:33-8. 
49. Coskun G, Ozgur H. Molecular Mechanism of Apoptosis and Necrosis. Arch Med Rev J. 2011;20:145-58.

50. Salzer S, Rosema NAM, Maertin ECJ, Slot DE, Timmer CJ, Dorfer CE, et al. The effectiveness of dentifrices without and with sodium lauryl sulfate on plaque, gingivitis and gingival abrasion- a randomized clinical trial. Clin Oral Invet. 2016;20:443-50.

51. Healy CM, Paterson M, Joyston-Bechal S, Williams DM, Thornhill MH. The effect of a sodium lauryl sulfate-free dentifrice on patients with recurrent oral ulceration. Oral Dis. 1999;5:39-43.

52. Barkvoll P, Rolla G, Svendsen AK. Interaction between chlor- hexidine digluconate and sodium lauryl sulfate in vivo. J Clin Periodontol. 1989;16:593-5.

53. Allen AL, Hawley CE, Cutright DE, Seibert JS. An investigation of the clinical and histologic effects of selected dentifrices on human palatal mucosa. J Periodontol. 1975;46:102-12.

54. Shim YJ, Choi JH, Ahn HJ, Kwon JS. Effect of sodium lauryl sulfate on recurrent aphthous stomatitis: a randomized controlled clinical trial. Oral Dis. 2012;18:655-60.

55. Moore C, Addy M, Moran J. Toothpaste detergents: a potential source of oral soft tissue damage? Int J Dent Hyg. 2008;6:193-8.

56. Herlofson BB, Brodin P, Aars H. Increased Human Gingival Blood Flow Induced by Sodium Lauryl Sulfate. J Clin Periodontol. 1996;123:1004-7.

57. Melsen B, Rolla G. Reduced Clinical effect of monofluorophosphate in the presence of sodium lauryl sulphate. Caries Res, 1983;17:549-53.

58. Rantanen I, Jutila K, Nicander I, Tenovuo J, Soderling E. The effects of two sodium lauryl sulphatecontaining toothpastes with and without betaine on human oral mucosa in vivo. Swed Dent J. 2003;27:31-4.

59. Semlali A, Chakir J, Goulet JP, Chmielwski W, Rouabhia M. Whole cigarette smoke promets human gingival epithelial cell apoptosis and inhibits cell repair processes. J Periodont Res. 2011;46: 53341.

60. Rouabhia M. Interactions between host and oral commensal microorganisms are key events in health and disease status. Can J Infect Dis. 2002;13: 47-51.

61. Weindl G, Wagener J, Schaller M. Epithelial cells and innate antifungal defense. J Dent Res. 2010;89: 666-75.

62. Bahri R, Saidane-Mosbahi D, Rouabhia M. Candida famata modulates toll-like receptor, betadefensin, and proinflammatory cytokine expression by normal human epithelial cells. J Cell Physiol. 2010;222: 209-18.

\section{Tables}

Table 1

Composition of materials evaluated

Page $13 / 24$ 


\begin{tabular}{|c|c|c|}
\hline Materials & Composition & Manufacturer \\
\hline Colgate 6+ & $\begin{array}{l}\text { Sorbitol, aqua, hydrated silica, PEG-12, Sodium Lauryl Sulfate, } \\
\text { cellulose gum, sodium saccharin, sodium fluoride (1450 ppm F-), } \\
\text { aroma,hydroxypropyl methylcellulose, menthol, glycerin, cinnamal, } \\
\text { eugenol, limonene, Cl 77891, Cl } 42090\end{array}$ & $\begin{array}{l}\text { Colgate } \\
\text { Palmolive } \\
\text { Company, } \\
\text { Belgium }\end{array}$ \\
\hline $\begin{array}{l}\text { Nenedent } \\
\text { Kids }(4-9 \\
\text { aged) }\end{array}$ & $\begin{array}{l}\text { Aqua, hydrated silica, glycerin, xylitol, propylene glycol, xanthan gum, } \\
\text { titanium dioxide, aroma, Sodium Lauryl Sarcosinate, disodium EDTA, } \\
\text { sodiummonofluorophophate ( } 500 \text { ppm F-), sodium chloride }\end{array}$ & $\begin{array}{l}\text { Dentinox, } \\
\text { Berlin, } \\
\text { Germany }\end{array}$ \\
\hline $\begin{array}{l}\text { Perlodent } \\
\text { Junior } 6+\end{array}$ & $\begin{array}{l}\text { Aqua, sorbitol, hydrated silica, propylene glycol, tetrapotassium } \\
\text { pyrophosphate, xanthan gum, Sodium C14-16 Olefin } \\
\text { Sulfonate, aroma, titanium dioxide, sodium fluoride (1450 ppm F-), } \\
\text { sodium saccharin, phenoxyethanol, ethylhexyl glycerin }\end{array}$ & $\begin{array}{l}\text { Rossmann, } \\
\text { Germany }\end{array}$ \\
\hline $\begin{array}{l}\text { Sensodyne } \\
\text { Pronamel } \\
6+\end{array}$ & $\begin{array}{l}\text { Aqua, sorbitol, hydrated silica, glycerin, PEG-6, Cocamidopropyl } \\
\text { Betaine, xanthan gum, aroma, sodium fluoride }\left(1450 \mathrm{ppm} \mathrm{F}^{-}\right) \text {, , sodium } \\
\text { saccharin, sucralose, titanium dioxide, sodium hydroxide, limonene }\end{array}$ & $\begin{array}{l}\text { Glaxo Smith } \\
\text { Kline, ABD }\end{array}$ \\
\hline $\begin{array}{l}\text { Splat } \\
\text { Juicy }\end{array}$ & $\begin{array}{l}\text { Aqua*, dicalcium phosphate dihydrate*, hydrogenated starch } \\
\text { hydrolsate* }^{\star} \text { glycerin*, hydroxyapatite, cellulose gum*, aroma, xanthan } \\
\text { gum*, potassium thiocyanate, lactoferrin*, lactoperoxidase*, glucose } \\
\text { oxidase }^{\star} \text { glucose pentaacetate, aloe barbadensis leaf extract*, } \\
\text { sodium mthylparaben, hydrolyzed casein*, glycyrrhiza glabra root } \\
\text { extract* (*natural origins) }\end{array}$ & \\
\hline $\begin{array}{l}\text { Complete } \\
\text { DMEM } \\
\text { (CDMEM) }\end{array}$ & $\begin{array}{l}\text { \%10 oranında FBS (Fötal sığır serumu), \%1 penisilin/ streptomycin } \\
\text { ilave edilmiş DMEM (Dulbecco's Modified Eagles Medium) }\end{array}$ & $\begin{array}{l}\text { Gibco, Grand } \\
\text { Island, USA }\end{array}$ \\
\hline
\end{tabular}

Table 2

Comparison of viability of gingival epithelial cells between groups 


\begin{tabular}{|c|c|c|c|c|}
\hline & \multicolumn{4}{|l|}{ Concentration } \\
\hline & $0,40 \%$ & $20 \%$ & $50 \%$ & $80 \%$ \\
\hline Colgate 6+ & $75.74 \pm 3.18 a$ & $47.56 \pm 3.49 a$ & $30.77 \pm 4.26 a$ & $13.04 \pm 2.98 a$ \\
\hline Splat Juicy & $90.14 \pm 0.95 d$ & $85.1 \pm 1.77 b$ & $84.82 \pm 1.6 b$ & $83.19 \pm 1.88 b$ \\
\hline Sensodyne Pronamel 6+ & $84.66 \pm 1.58 c$ & $78.8 \pm 1.16 c$ & $67.47 \pm 1.68 c$ & $57.63 \pm 0.83 c$ \\
\hline Nenedent Kids & $80.23 \pm 0.93 b$ & $64.21 \pm 0.91 d$ & $55.17 \pm 1.2 d$ & $39.15 \pm 0.91 d$ \\
\hline Perlodent Junior 6+ & $78.66 \pm 1.84 a b$ & $64.75 \pm 0.91 d$ & $45.21 \pm 1.81 \mathrm{e}$ & $30.43 \pm 4.05 e$ \\
\hline CDMEM & $90.82 \pm 1.04 d$ & $9 ., 82 \pm 1.04 \mathrm{e}$ & $90.82 \pm 1.04 f$ & $90.82 \pm 1.04 f$ \\
\hline $\mathbf{p}$ & $0.000^{*}$ & $0.000^{\star}$ & $0.000^{\star}$ & $0.000^{*}$ \\
\hline $\begin{array}{l}\text { a-b-c-d-e-f: There is no dif } \\
\text { One Way ANOVA Test; Tu } \\
\text { * Significant } p \text { value at } 0 .\end{array}$ & $\begin{array}{l}\text { erence between th } \\
\text { key post-hoc Test } \\
5 \text { level }\end{array}$ & groups with the & same & \\
\hline
\end{tabular}

Table 3

Comparison of early apoptotic cell rates ingingival epithelial cells between groups 


\begin{tabular}{|c|c|c|c|c|}
\hline & \multicolumn{4}{|c|}{ Concentration } \\
\hline & $0,40 \%$ & $20 \%$ & $50 \%$ & $80 \%$ \\
\hline Colgate 6+ & $3.38 \pm 2.01$ & $9.75 \pm 3.55 \mathrm{~cd}$ & $33.83 \pm 2.81 \mathrm{~d}$ & $28.11 \pm 3.07 b$ \\
\hline Splat Juicy & $3.12 \pm 1.48$ & $2.52 \pm 1.14 \mathrm{a}$ & $2.29 \pm 0.78 a$ & $1.97 \pm 0.4 a$ \\
\hline Sensodyne Pronamel 6+ & $1.85 \pm 0.53$ & $4.52 \pm 0.67 a b$ & $12.09 \pm 1.11 \mathrm{c}$ & $9.73 \pm 0.57 c$ \\
\hline Nenedent Kids & $4.24 \pm 0.98$ & $10.55 \pm 1.79 d$ & $8.69 \pm 1.36 b$ & $38.08 \pm 1.27 d$ \\
\hline Perlodent Junior 6+ & $2.83 \pm 0.67$ & $6.39 \pm 1.14 b c$ & $10.9 \pm 0.99 b c$ & $17.82 \pm 3.44 \mathrm{e}$ \\
\hline CDMEM & $2.24 \pm 1.26$ & $2.24 \pm 1.26 a$ & $2.24 \pm 1.26 \mathrm{a}$ & $2.24 \pm 1.26 a$ \\
\hline p & 0.078 & $0.000 *$ & $0.000^{\star}$ & $0.000 *$ \\
\hline \multicolumn{5}{|c|}{ a-b-c-d-e-f: There is no difference between the groups with the same } \\
\hline \multicolumn{5}{|c|}{ One Way ANOVA Test ; Tukey post-hoc Test } \\
\hline \multicolumn{5}{|c|}{ * Significant $p$ value at 0.05 level } \\
\hline
\end{tabular}

Table 4

Comparison of late apoptotic cell rates ingingival epithelial cells between groups 


\begin{tabular}{|c|c|c|c|c|}
\hline & \multicolumn{4}{|l|}{ Concentration } \\
\hline & $0,40 \%$ & $20 \%$ & $50 \%$ & $80 \%$ \\
\hline Colgate 6+ & $5.73 \pm 1.66 c$ & $11.23 \pm 3.2 c$ & $10.29 \pm 2.55 b$ & $37.19 \pm 2.68 \mathrm{e}$ \\
\hline Splat Juicy & $1.93 \pm 0.32 a b$ & $3.51 \pm 0.65 a$ & $3.87 \pm 0.96 a$ & $3.46 \pm 0.97 a b$ \\
\hline Sensodyne Pronamel 6+ & $0.70 \pm 0.37 a$ & $1.5 \pm 0.37 a$ & $5.25 \pm 0.64 a$ & $11.96 \pm 1.02 c$ \\
\hline Nenedent Kids & $0.89 \pm 0.26 a$ & $7.65 \pm 1 b$ & $12.31 \pm 0.53 b$ & $7.65 \pm 0.6 b c$ \\
\hline Perlodent Junior 6+ & $6.13 \pm 1.01 c$ & $3.66 \pm 0.64 a$ & $10.9 \pm 1.19 b$ & $18.78 \pm 4.84 d$ \\
\hline CDMEM & $2.97 \pm 0.86 b$ & $2.97 \pm 0.86 a$ & $2.97 \pm 0.86 a$ & $2.97 \pm 0.86 a$ \\
\hline $\mathbf{p}$ & $0.000^{\star}$ & $0.000^{\star}$ & $0.000^{\star}$ & $0.000^{\star}$ \\
\hline $\begin{array}{l}\text { a-b-c-d-e-f: There is no dift } \\
\text { One Way ANOVA Test; Tu } \\
\text { * Significant } p \text { value at } 0 .\end{array}$ & $\begin{array}{l}\text { erence between } t \\
5 \text { level post-hoc Te }\end{array}$ & e groups with & e same & \\
\hline
\end{tabular}

Table 5

Comparison of necrotic cell rates ingingival epithelial cells between groups

\begin{tabular}{|c|c|c|c|c|}
\hline & \multicolumn{4}{|l|}{ Concentration } \\
\hline & $0,40 \%$ & $20 \%$ & $50 \%$ & $80 \%$ \\
\hline Colgate 6+ & $15.16 \pm 2.4 c$ & $31.46 \pm 4 \mathrm{e}$ & $25.11 \pm 2.91 d$ & $21.67 \pm 2.84 c$ \\
\hline Splat Juicy & $4.79 \pm 0.54 a$ & $8.86 \pm 0.87 b$ & $9.03 \pm 1.03 b$ & $11.39 \pm 1.53 b$ \\
\hline Sensodyne Pronamel 6+ & $12.79 \pm 0.96 b c$ & $15.18 \pm 1.09 c$ & $15.19 \pm 1.28 c$ & $20.69 \pm 0.91 c$ \\
\hline Nenedent Kids & $14.65 \pm 0.61 b c$ & $17.6 \pm 1.1 \mathrm{c}$ & $23.83 \pm 0.7 d$ & $15.15 \pm 0.92 b$ \\
\hline Perlodent Junior 6+ & $12.35 \pm 0.68 b$ & $25.21 \pm 1.3 d$ & $31.99 \pm 1.2 \mathrm{e}$ & $32.97 \pm 3.99 d$ \\
\hline CDMEM & $3.98 \pm 1.09 a$ & $3.98 \pm 1.09 a$ & $3.98 \pm 1.09 a$ & $3.98 \pm 1.09 a$ \\
\hline p & $0.000^{\star}$ & $0.000 *$ & $0.000 *$ & $0.000 *$ \\
\hline \multicolumn{5}{|c|}{ a-b-c-d-e-f: There is no difference between the groups with the same } \\
\hline \multicolumn{5}{|c|}{ One Way ANOVA Test; Tukey post-hoc Test } \\
\hline \multicolumn{5}{|c|}{ * Significant $p$ value at 0.05 level } \\
\hline
\end{tabular}




\section{Figures}

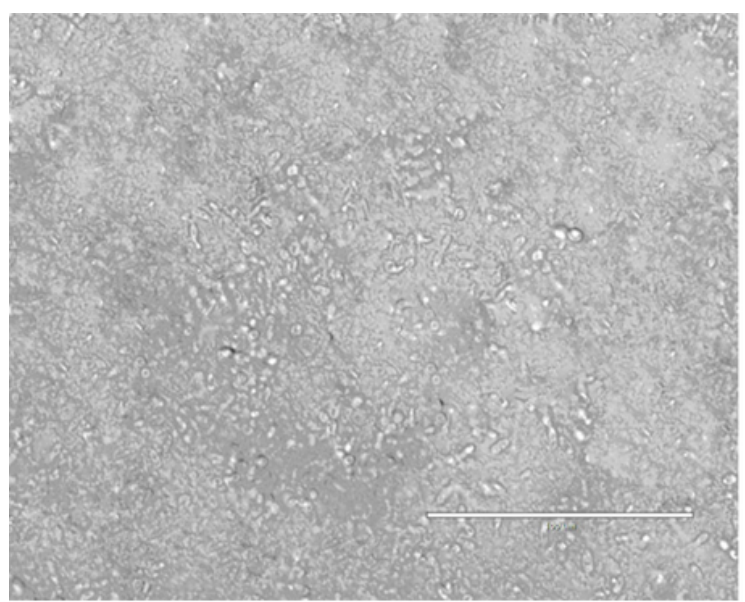

\section{PO GEC}

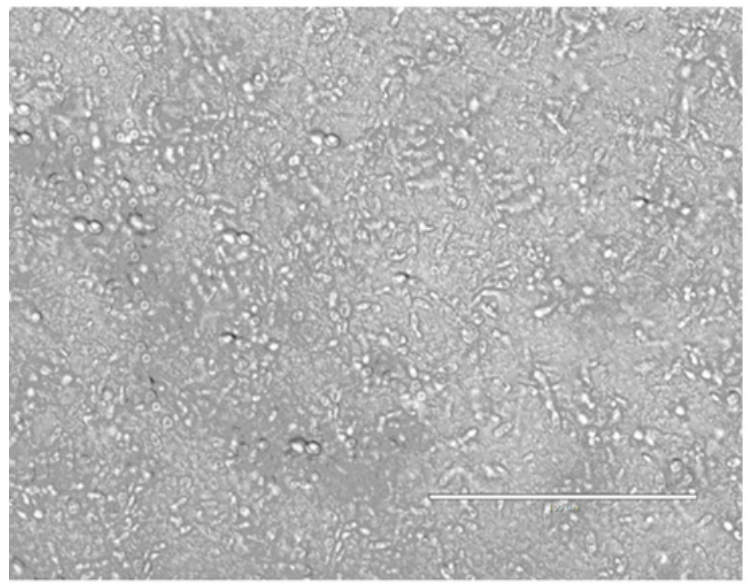

P2 GEC

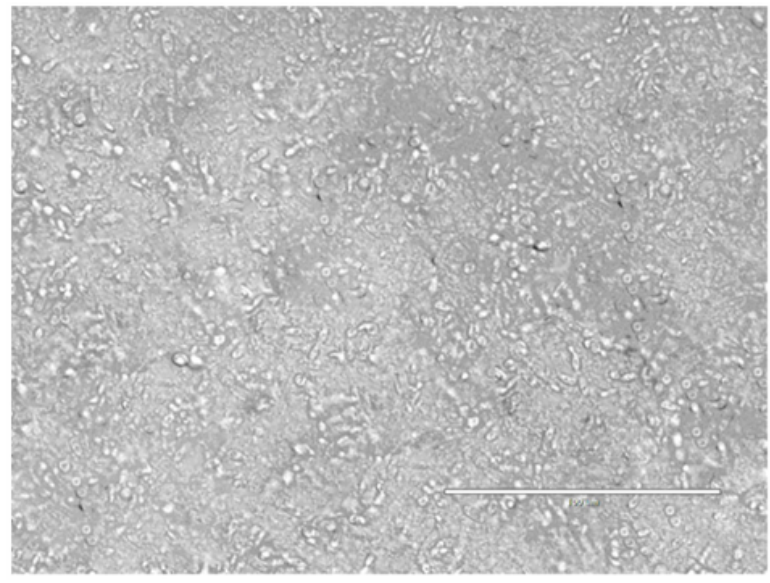

P1 GEC

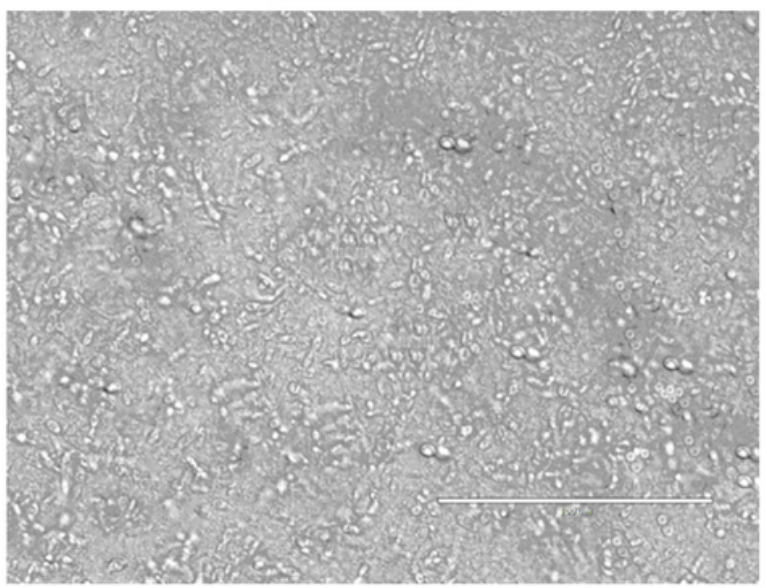

P3 GEC

\section{Figure 1}

Light microscope images of GECs in P0, P1, P2 and P3 passages

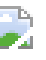

\section{Figure 2}

Determination of characterization of GECs by Binocular Research Microscope (Olympus BH2-RFCA) 400X Gingival epithelial cells, Binocular Research Microscope (Olympus BH2-RFCA) 400X 


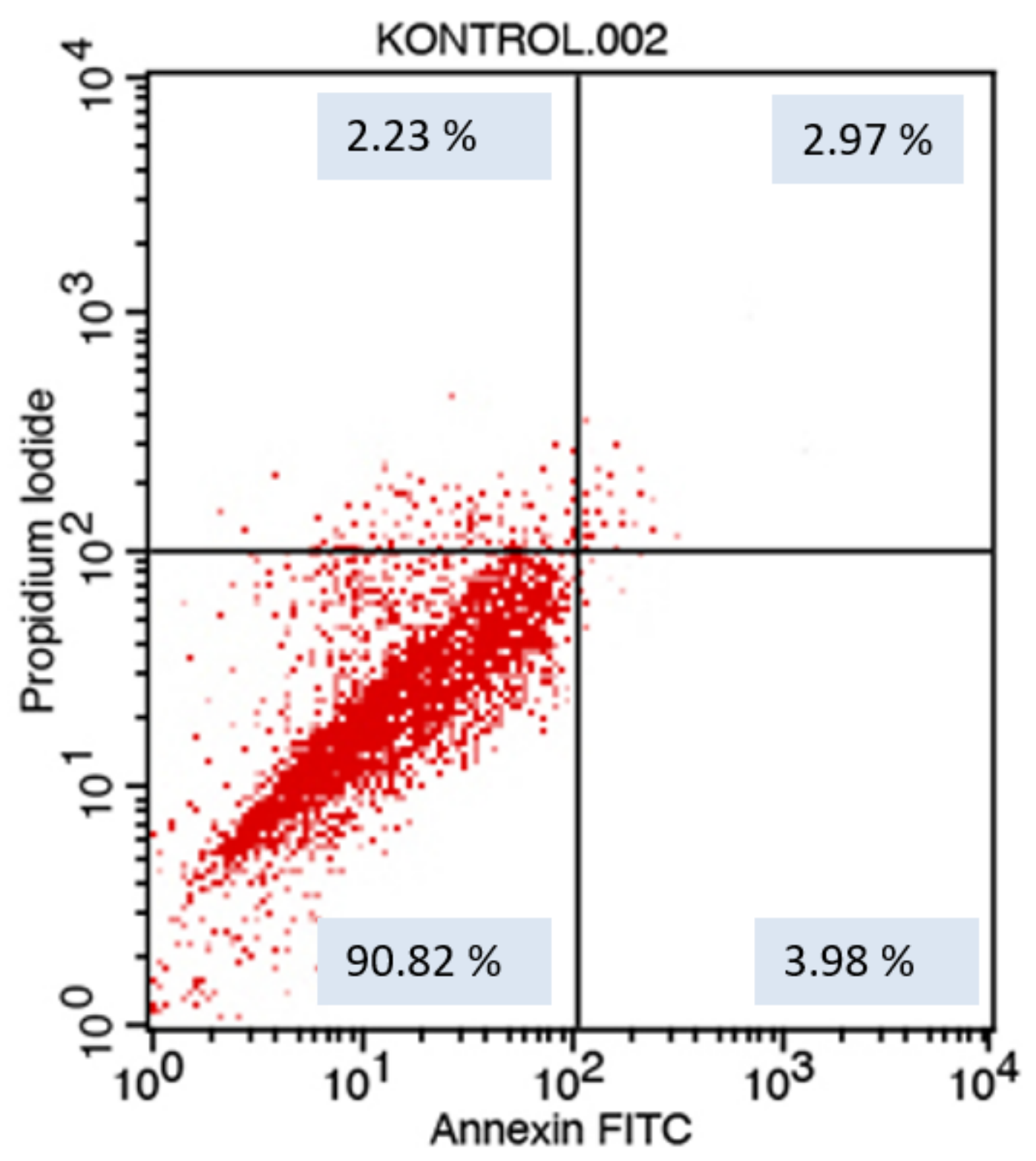

Figure 3

Flow cytometry graph related to the effect of CDMEM control group on gingival epithelial cells ( $\mathrm{x}$ : Annexin VFITC, y: PIPE) 

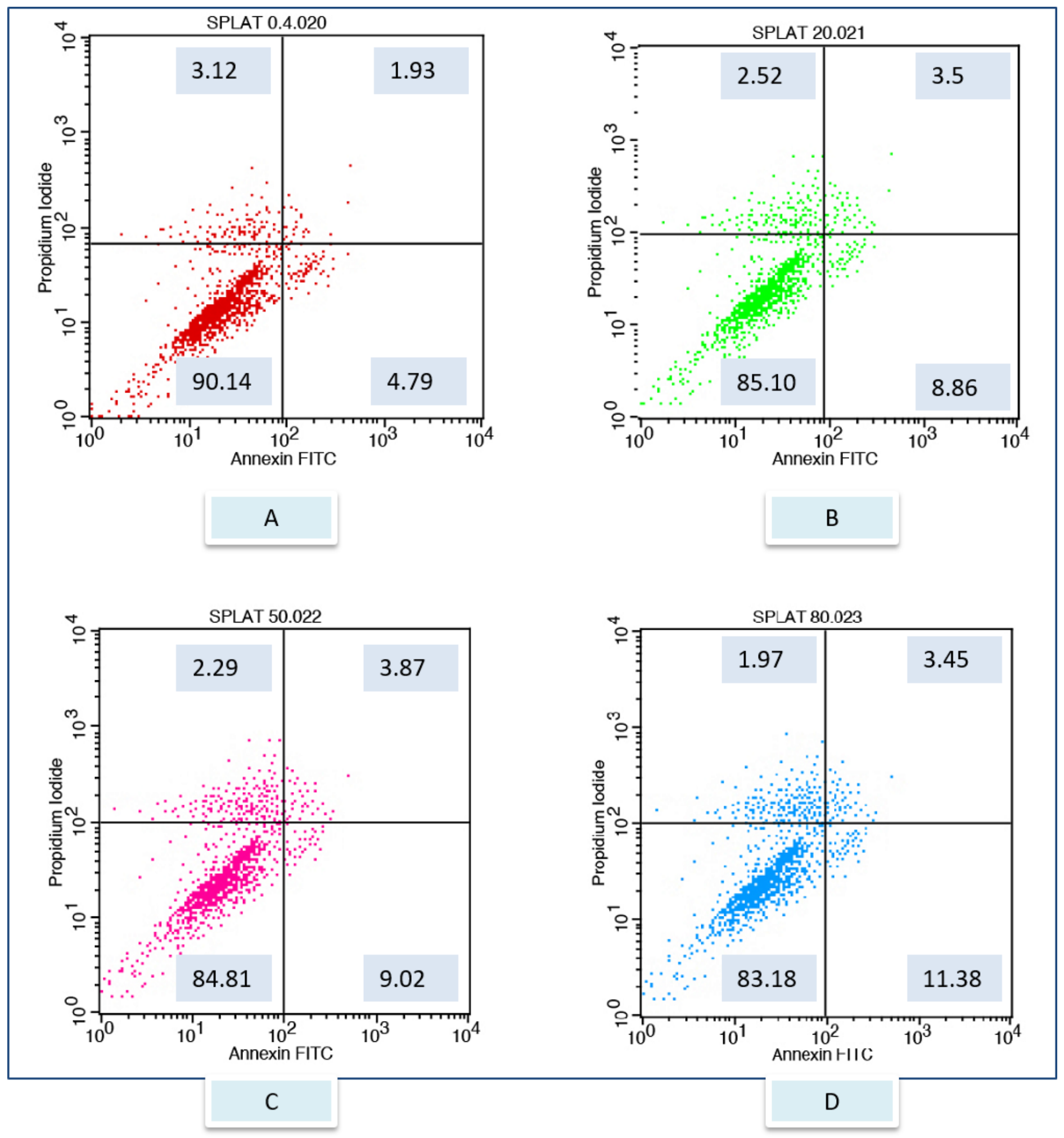

\section{Figure 4}

Flow cytometry graph related to the effect of Splat toothpaste solutions on gum epithelial cells ( $\mathrm{x}$ : Annexin V FITC, y: PIPE) A) Splat 0.4\% B) Splat 20\% C) Splat 50\% D) Splat $80 \%$ 


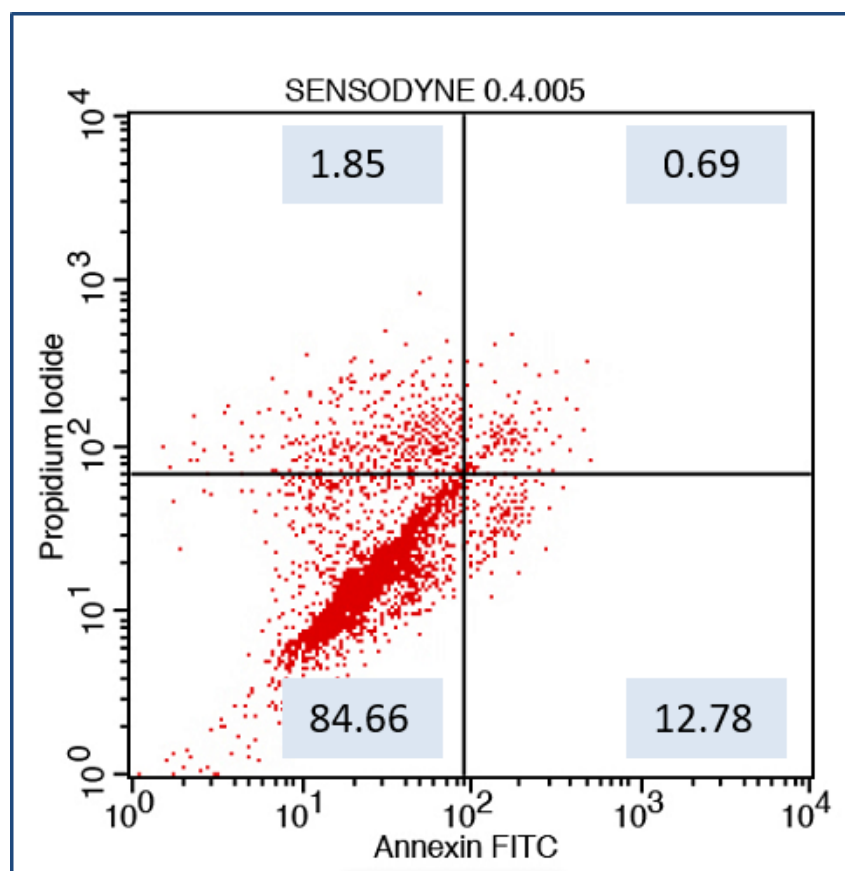

A

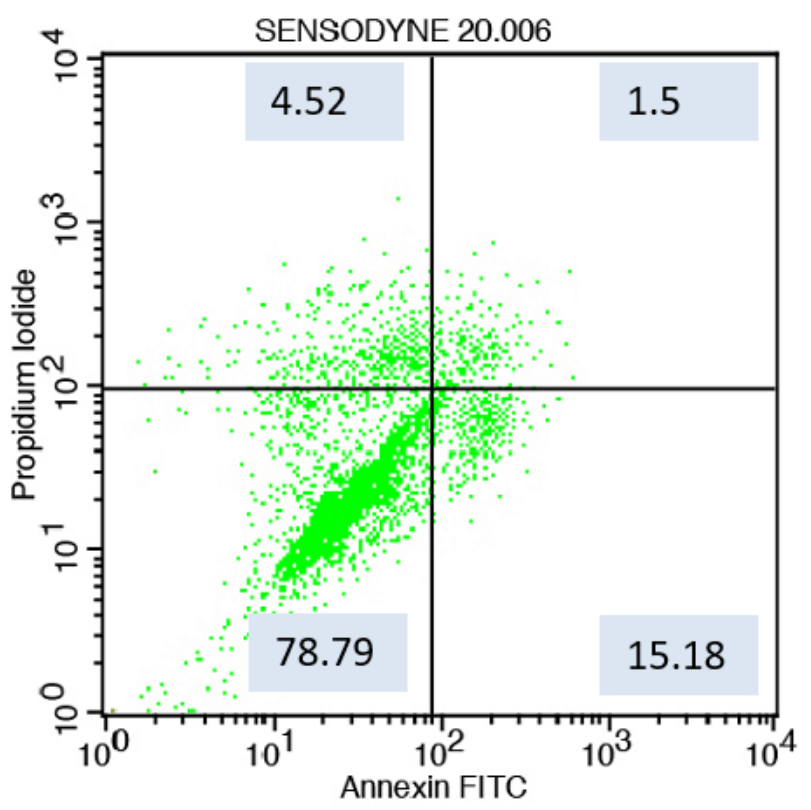

A

\section{B}
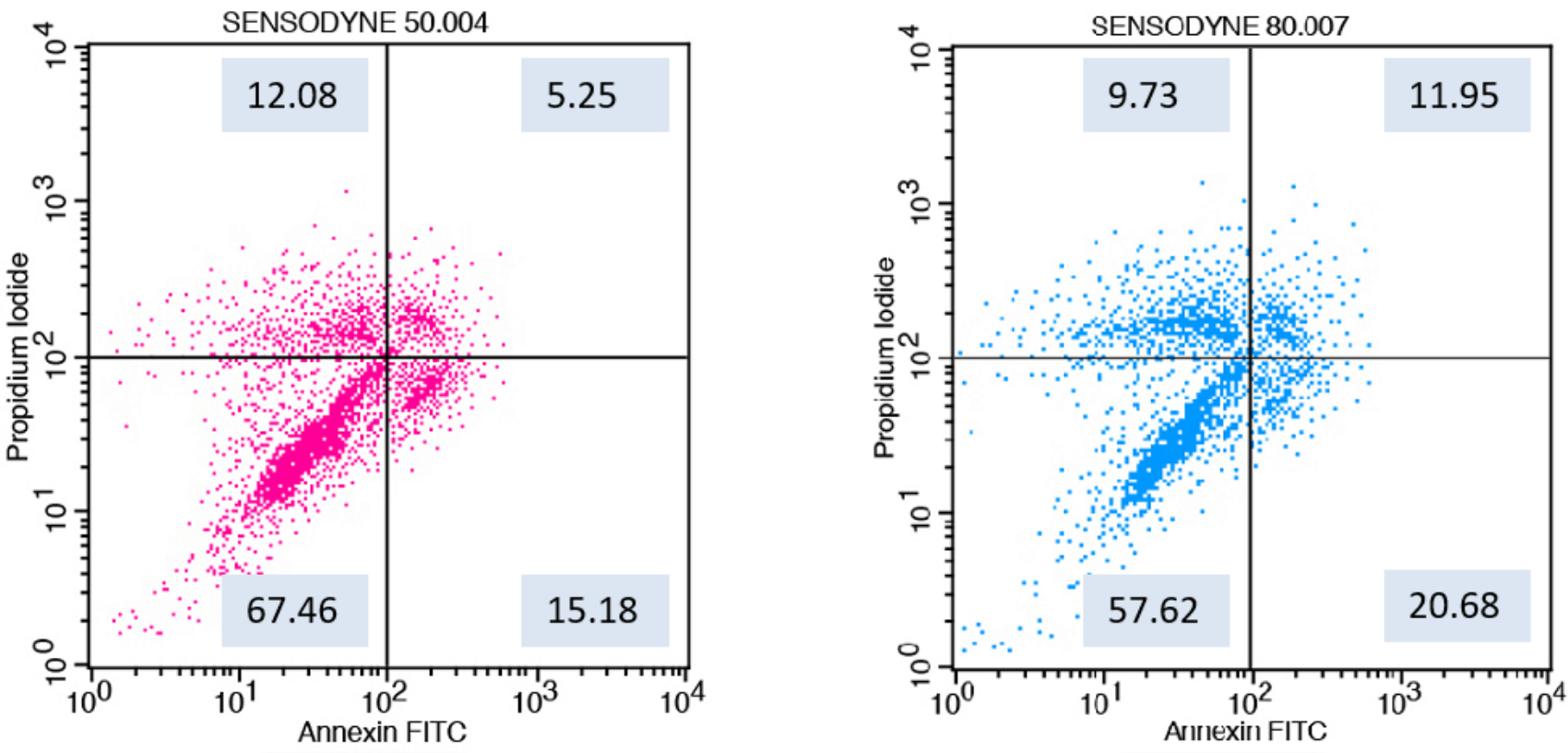

C

$\mathrm{D}$

\section{Figure 5}

Flow cytometry graph related to the effect of Sensodyne toothpaste solutions on gum epithelial cells (x: Annexin V FITC, y: PIPE) A) Sensodyne 0.4\% B) Sensodyne 20\% C) Sensodyne 50\% D) Sensodyne 80\% 


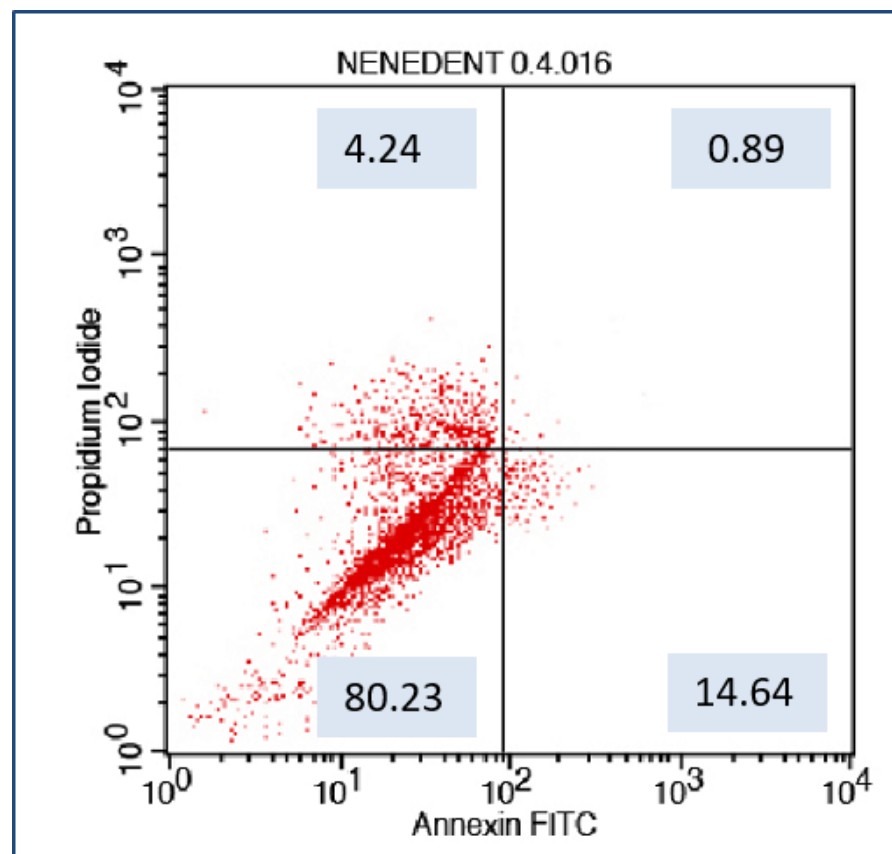

A
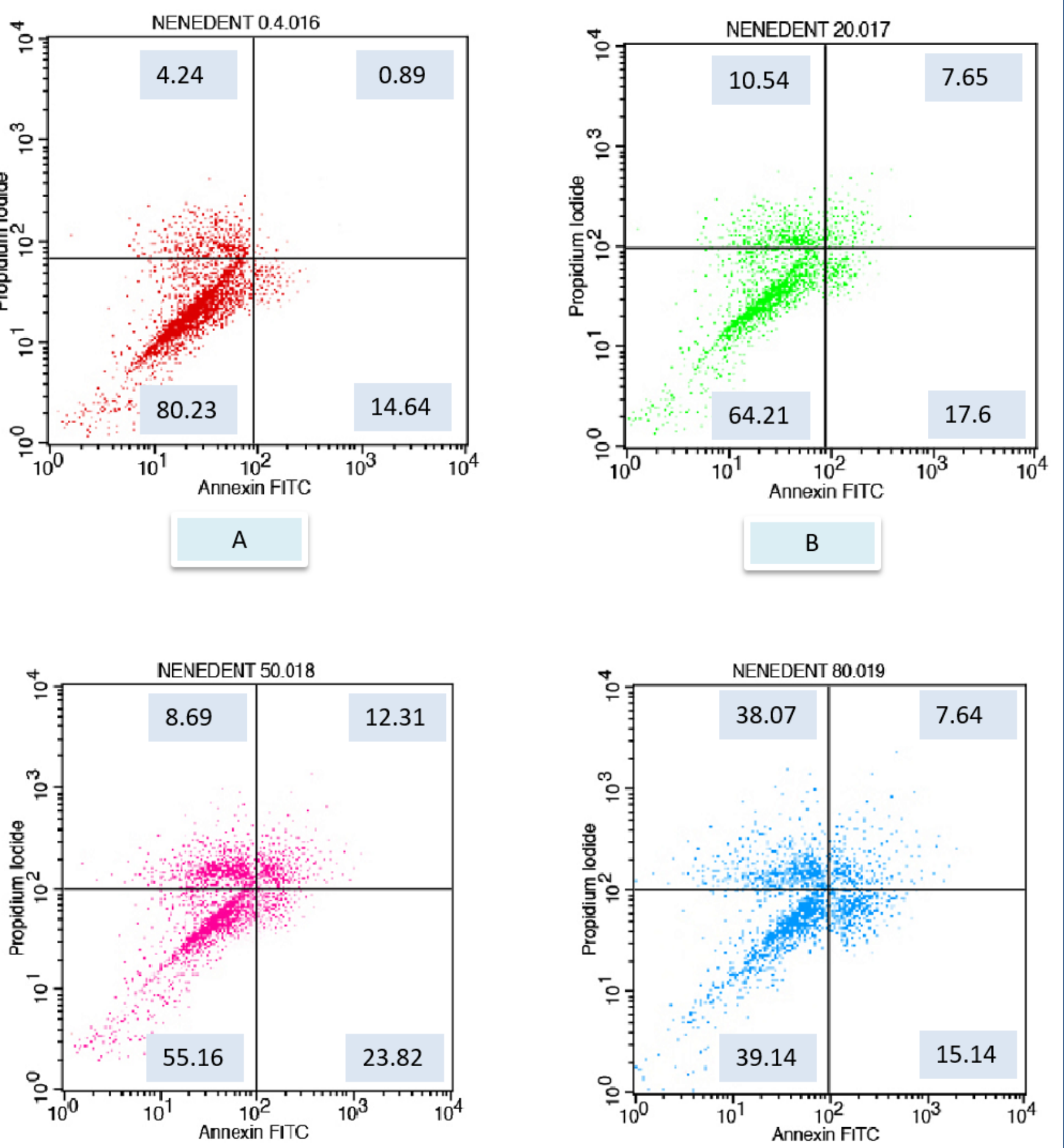

C

D

\section{Figure 6}

Flow cytometry graph related to the effect of nenedent toothpaste solutions on gum epithelial cells ( $\mathrm{x}$ : Annexin V FITC, y: PIPE) A) Nenedent $0.4 \%$ B) Nenedent 20\% C) Nenedent 50\% D) Nenedent $80 \%$ 

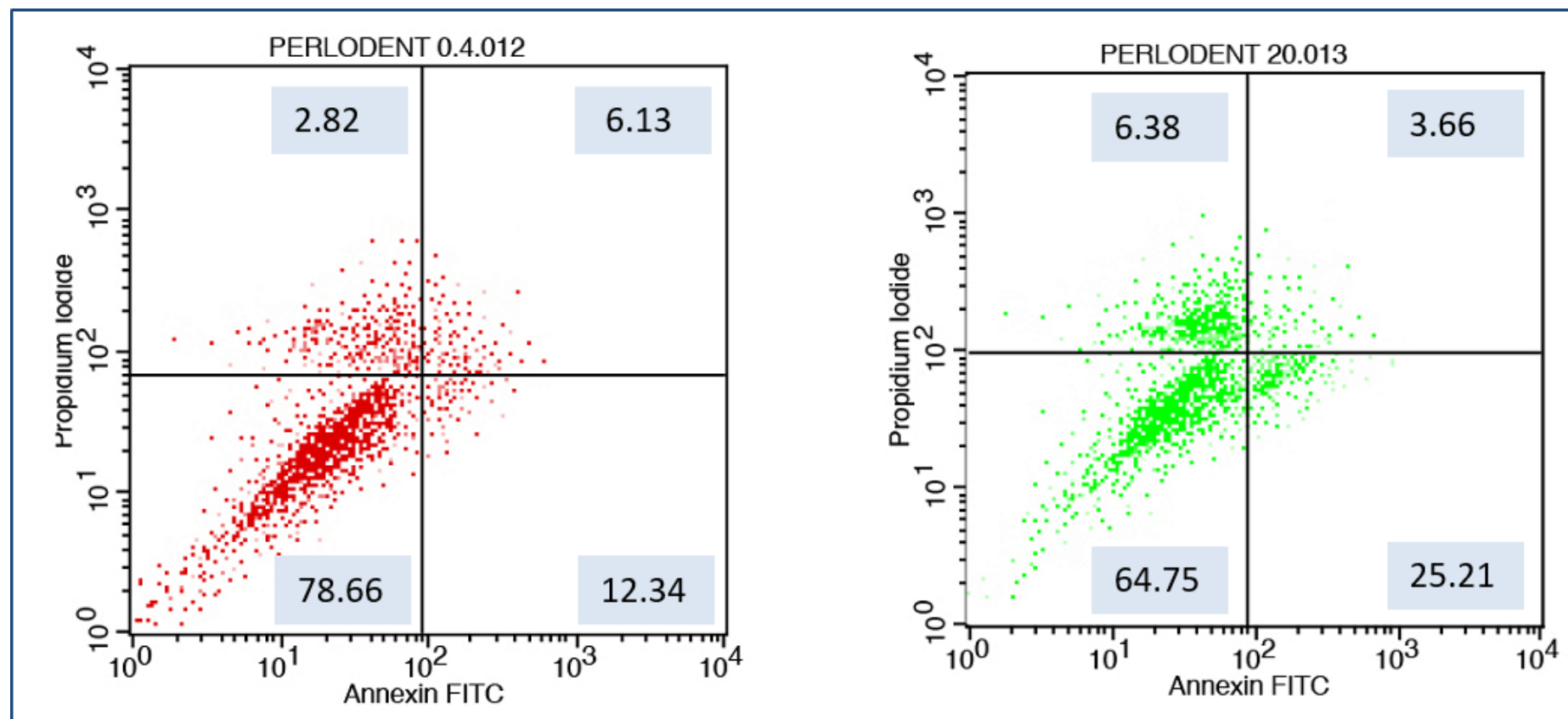

A

B
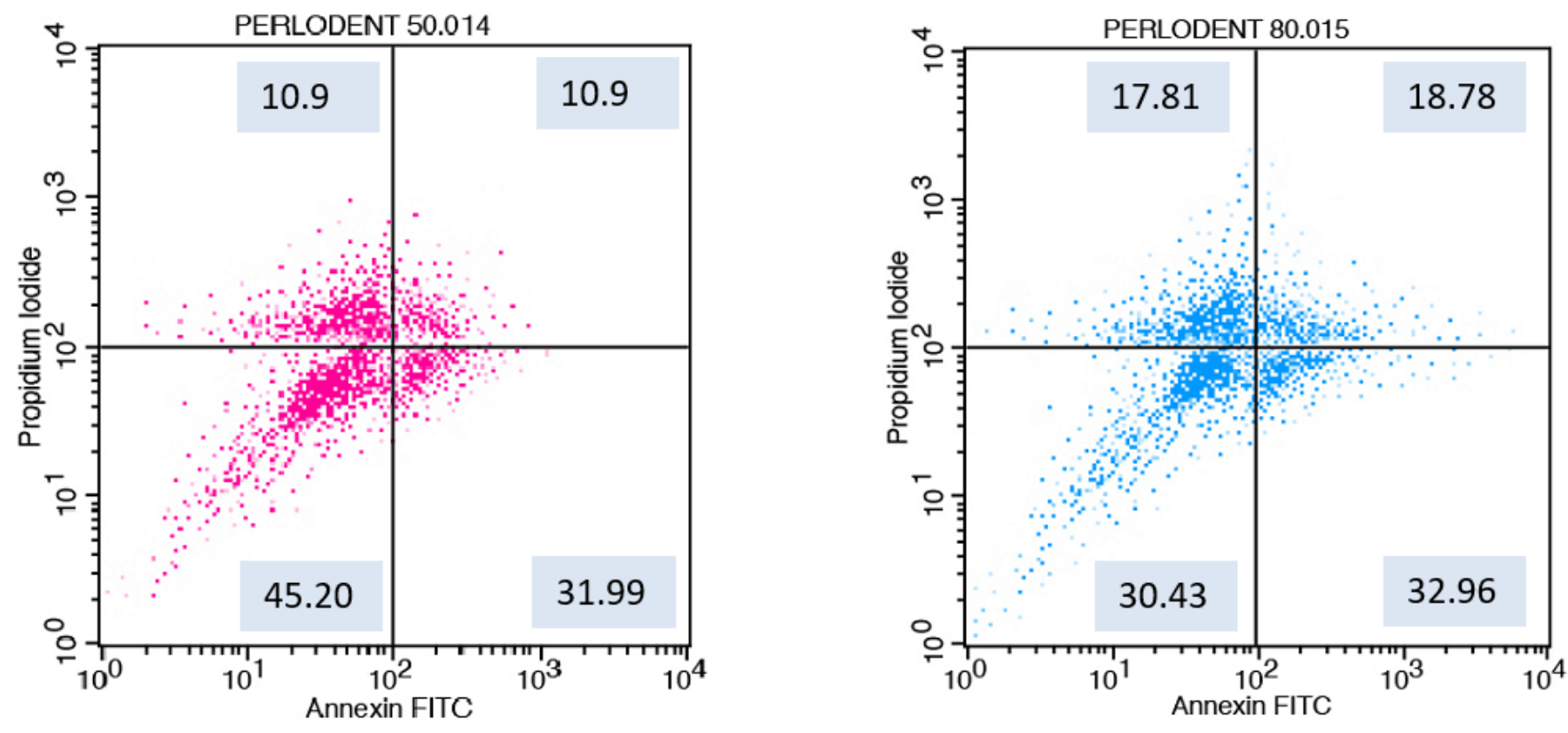

C

D

\section{Figure 7}

Flow cytometry graph related to the effect of perlodent toothpaste solutions on gum epithelial cells ( $\mathrm{x}$ : Annexin V FITC, y: PIPE) A) Perlodent 0.4\% B) Perlodent 20\% C) Perlodent 50\% D) Perlodent $80 \%$ 


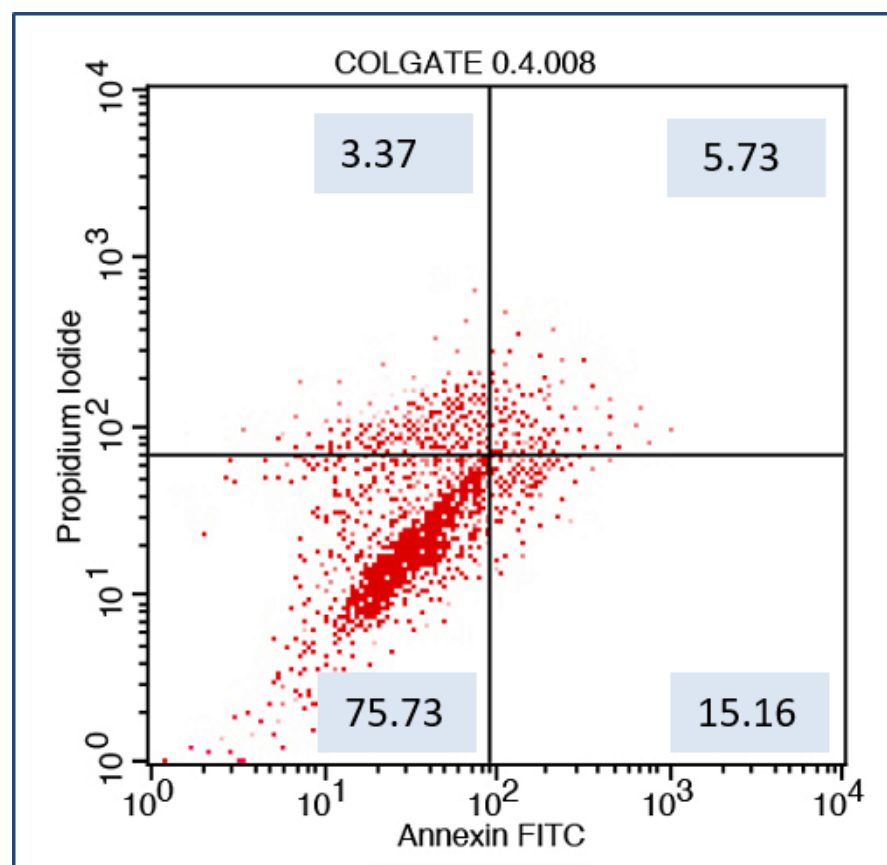

A
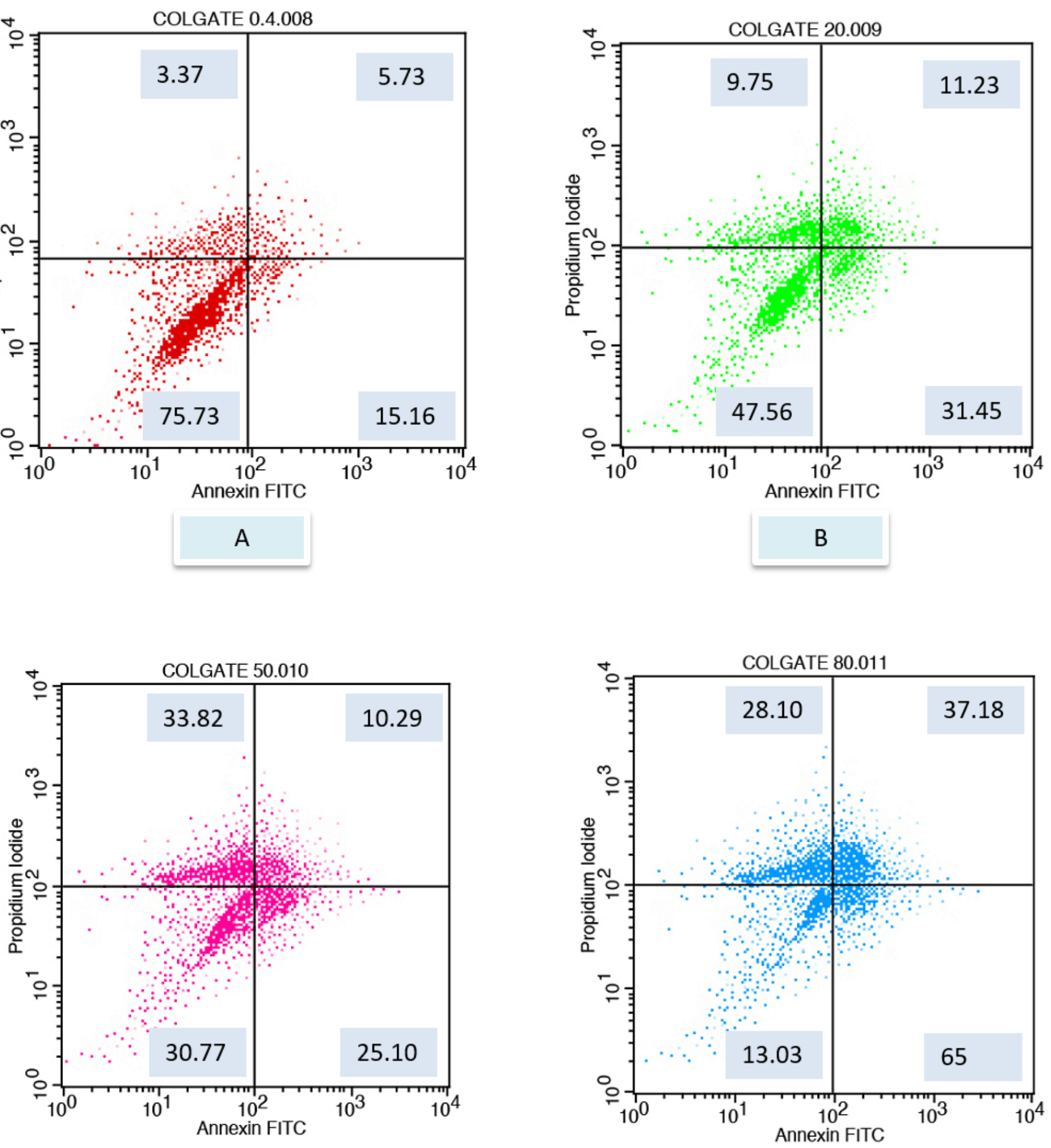

C

D

\section{Figure 8}

Flow cytometry graph related to the effect of Colgate toothpaste solutions on gum epithelial cells ( $\mathrm{x}$ : Annexin V FITC, y: PIPE) A) Colgate $0.4 \%$ B) Colgate $20 \%$ C) Colgate $50 \%$ D) Colgate $80 \%$ 